\title{
GENOTOXIC EFFECTS OF DITHANE, MALATHION AND GARDEN RIPCORD ON ONION ROOT TIP CELLS
}

\section{Asita $\mathbf{O A}^{1^{*}}$ and $\mathbf{R}$ Makhalemele ${ }^{2}$}

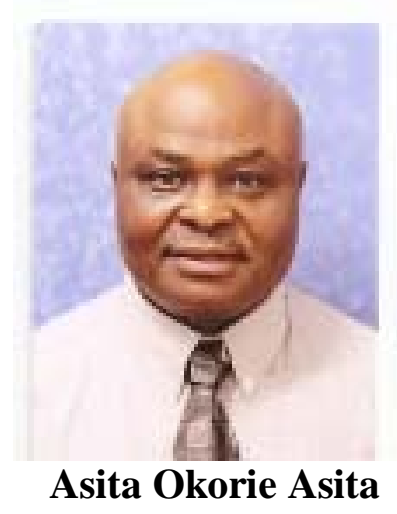

*Corresponding author email: ao.asita@nul.ls

Department of Biology, National University of Lesotho, P.O. Roma 180 Maseru, Lesotho.

${ }^{2}$ Biology Department, National University of Lesotho, P.O. Roma 180 Maseru, Lesotho. 


\begin{abstract}
Over the past decade, issues of animal use and care in toxicology research and testing have become one of the fundamental concerns for both science and ethics. Emphasis has been given to the use of alternatives to mammals in testing, research and education. Because plants are direct recipients of agrotoxics and therefore important material for genetic tests and for environmental monitoring of places affected by such pollutants, three doses each of the pesticides, dithane $(0.196,0.391,0.782 \%$ solution), malathion $(0.034,0.069,0.137 \%$ solution) and garden ripcord (1.015, $2.030,4.060 \%$ solution) were assessed for cytotoxicity and genotoxicity to onion root tip cells. The doses represented the LC50 (dose that inhibited $50 \%$ of seeds from germinating), $1 / 2$ LC50 and $1 / 4$ LC50 for each pesticide that were determined in a preliminary dose selection experiment. Onion seeds were germinated on moistened filter paper in a petri dish at room temperature until radicles appeared. Germinated seeds were exposed to three concentrations of each pesticide for 20 hours. About 1$2 \mathrm{~mm}$ length of root tip was cut, fixed in acetic alcohol, washed in ice cold water, hydrolyzed in warm $1 \mathrm{~N}$ hydrochloric acid, stained with aceto-carmine and squashed on glass microscope slide. About 3000 cells were scored for each treatment and classified into interphase and normal or aberrant division stage. Cytotoxicity was determined by calculating the mitotic indices and comparing the mitotic indices of treated cells at each dose of each pesticide with that of the negative control group. The mitotic index of the negative control group was reduced to half or less, at the two highest doses of all three pesticides. All three pesticides were therefore cytotoxic to the onion root tip cells. Genotoxicity was measured by comparing the number of cells/1000 in the aberrant division stages at each dose of each pesticide with the number of such cells in the negative control group using the Mann-Whitney statistical test. Dithane was genotoxic $(\mathrm{P}<0.05)$, inducing multipolar anaphases and telophases and lagging chromosomes. Malathion was genotoxic $(\mathrm{P}<0.05)$, inducing lagging chromosomes. Garden ripcord was not genotoxic.
\end{abstract}

Key words: Allium cepa, cytotoxicity, genotoxicity, pesticides

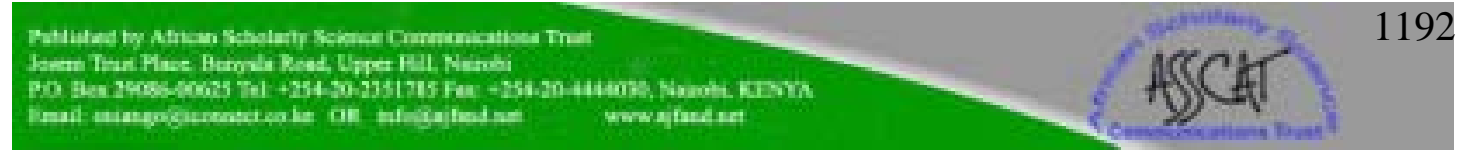




\section{INTRODUCTION}

Pesticides are used all over the world and, in recent years, their use has increased spectacularly because it has greatly improved agricultural yield through inhibition of disease causing organisms and by acting against pests in the field and during storage of agricultural products [1]. Large amounts of these chemicals are released into the environment and many of them affect non-target organisms, being a potential hazard to human health. Pesticide exposure is ubiquitous, due not only to agricultural pesticide use and contamination of foods, but also to the extensive use of these products in and around residences [2]. As at 2001, there were 834 active pesticide substances registered in the European Union, some of which have been classified as possible or probable mutagens and/or carcinogens by the International Agency for Research on Cancer [3, 4].

Over the past decade, issues of animal use and care in toxicology research and testing have become one of the fundamental concerns for both science and ethics. Emphasis has been given to the use of alternatives to mammals in testing, research and education [5].

The Allium cepa assay is an efficient test for chemical screening and in-situ monitoring for genotoxicity of environmental contaminants and has been widely used to study genotoxicity of many pesticides revealing that these compounds can induce chromosomal aberrations in root meristems of $A$. cepa $[6,7]$. Because of the potential environmental and human health impact connected with the heavy use of pesticides, the pesticides, dithane, malathion and garden ripcord were assessed for inhibition of cell division (cytoxicity) and genotoxicity using the Allium cepa chromosome aberration assay, in which many environmental chemicals have not been evaluated.

Dithane, also known as mancozed belongs to a class of chemicals known as ethylene bisdithiocarbamates (EBDCs). The EBDCs are fungicides used to prevent crop damage in the field and to protect harvested crops from deterioration during storage or transport [8]. The ethylene bisdithiocarbamate pesticides are generally considered to have low short-term mammalian toxicity. A major toxicological concern, however, is ethylenethiourea (ETU), an industrial contaminant and a breakdown product of mancozeb and other EBDC pesticides [9].

A data gap exists in the information available on the mutagenicity of mancozed and ETU. In the reverse mutation assay with Salmonella typhimurium tester strains TA97a, TA98, TA100, and TA102, mancozeb exhibited toxic effects at the dose of 40 $\mathrm{mg} / \mathrm{plate}$ and higher with all tester strains. Mancozed showed dose-dependent increases in the number of revertants with and without metabolic activation when it was dissolved in DMSO or acetone with strain TA97a [10]. In other investigations however, mancozeb was found to be mutagenic in one set of tests, while in another it did not cause mutations [8]. Mancozeb induced a dose-dependent increase in spindle morphology alterations in preovulatory oocytes of 23-25 day old Swiss CD1 mouse at $1 \mu \mathrm{g} / \mathrm{ml}$ in culture medium [11]. 
In addition to having the potential to cause goiter, ETU has produced birth defects and cancer in experimental animals. ETU has been classified as a probable human carcinogen by the EPA $[9,12]$.

Malathion, also known as carbophos, maldison and mercaptothion is an emulsifiable organophosphate concentrate non-systemic, wide spectrum insecticide for the control of garden and household pests [13]. A number of products containing malathion are also licensed as human medicines for use in the control of head lice [14]. The acute effects of malathion depend on product purity and the vehicle of administration [15]. A data gap exists in the information available on the mutagenicity of malathion. Malathion was toxic to the adrenal glands and the liver of rats, had effects on blood clotting time in test animals and produced detectable mutations in three different types of cultured human cells, including white blood cells and lymph cells [13]. There is evidence of non-carcinogenicity of malathion for humans [12].

Garden ripcord contains cypermethrin, a Type II synthetic pyrethroid insecticide, effective against a wide range of pests in agriculture, public health and animal husbandry $[16,17,18]$. The data on animal experiments with cypermethrin suggest that it has a potential for bioaccumulation in the body following continuous exposure and the metabolic profile due to all of its isomers is extremely complex [16, 17]. The major metabolic pathways for pyrethroids (including halogenated pyrethroids such as cyfluthrin, cypermethrin, and permethrin) are hydrolysis of the central ester bond, oxidative attacks at several sites, and conjugation reactions, to produce a complex array of primary and secondary water-soluble metabolites, such as carboxylic acid derivatives and phenoxybenzoic acid derivatives, that undergo urinary excretion as alcohols, phenols, carboxylic acids, and their glycine, sulfate, glucuronide, or glucoside conjugates $[18,19,20]$.

Cypermethrin was not mutagenic to Salmonella typhimurium TA 100 or TA 98, in the presence or absence of a rat liver activation system at concentrations of up to 1 $\mathrm{mg} / \mathrm{plate}$, showed no cytotoxicity to $\mathrm{V}_{79}$ Chinese hamster Cells and was not mutagenic for either genetic loci (OUA' and TG') in V79 cells at concentrations up to $20 \mu \mathrm{g} / \mathrm{ml}$, in the presence or absence of rat hepatocytes [21]. However, cypermethrin administered intraperitoneally at doses $\geq 30 \mathrm{mg} / \mathrm{kg}$ significantly increased the incidence of chromosomal aberrations and micronuclei in bone marrow and the percent of sperm with head abnormalities [22]. Cypermethrin was classified as a possible human carcinogen with evidence of non-carcinogenicity for humans [12].

\section{MATERIALS AND METHODS}

Onion seeds: variety of Texas Grano 502 P.R.R. Packed by Starke Ayres (Pty) Ltd at Gauteng, Republic of South Africa were, purchased from Maseru garden centre, Lesotho, Southern Africa. 
All the three pesticides namely, Malathion (mercaptothion $(500 \mathrm{~g} / \mathrm{l})$, Dithane (mancozed $(750 \mathrm{~g} / \mathrm{kg}$ ) and Garden ripcord (cypermethrin $(20 \mathrm{~g} / \mathrm{l})$, were products of Agro-Serve (Pty) Ltd of the Republic of South Africa.

Ethanol (Absolute) was a product of Associated Chemical Enterprises (PTY) LTD of the Republic of South Africa; Hydrochloric acid and Glacial acetic acid were products of UNILAB of the Republic of South Africa; Methyl methane-sulfonate (MMS, $99 \%$ ) was a product of ALDRICH, USA; Aceto-carmine stain from Carolina Biological Supply Company, USA.

\section{Preliminary dose selection experiment}

Preliminary dose selection experiment was conducted for each chemical with concentration ranges between ten times above and below the manufacturers recommended dose. However, in cases where no inhibition of germination was observed, higher doses were tested.

For each test, 50 onion seeds were spread on a filter paper moistened with a specific concentration of the pesticide in a petri dish and kept for 3 days at room temperature to germinate. The number of seeds that produced a radicle were recorded at the end of the three days and compared to the number of seeds that germinated in the concurrent water treated control to derive the percentage germinating at each concentration. The LC50 for each pesticide was determined from the curve of percentage germination against dose.

\section{Genotoxicity assay}

The method used was similar to the method of Matsumoto et al. [23]. Alium cepa (onion) seeds were germinated in petri dishes containing pesticide-soaked filter paper (test), water-soaked filter paper (negative control) or on filter paper soaked in aqueous solution of $1 \%$ methyl methanesulfonate (positive control). In this project, a discontinuous treatment protocol was used. Seeds were first soaked in distilled water until the radicles reached a length of about $2 \mathrm{~cm}$. Germinated seeds were transferred to petri plates containing chemicals at different doses in which they were left for 20 hours (acute treatment) at room temperature. At the end of the 20 hours exposure, some seeds were collected at random and assessed. The concentrations of each pesticide tested were; LC50, $1 / 2$ LC50 and $1 / 4$ LC50, as determined in the preliminary dose selection experiments.

\section{Root Harvest and Slide Preparation}

Root tips 1-2 cm long were cut and placed in a watch glass and fixed in acetic alcohol (Ethanol: Glacial acetic acid in 3:1 ratio) at $4-6{ }^{\circ} \mathrm{C}$ for 3 hours. The root tips were washed twice with ice cold water for 10 minutes each and allowed to dry. A solution of $1 \mathrm{~N} \mathrm{HCl}$ pre-heated to $60{ }^{\circ} \mathrm{C}$ was added to the root tips in the watch glass for 10 minutes and the $\mathrm{HCl}$ was discarded. The $\mathrm{HCl}$ treatment was repeated a second time. Two root tips were transferred to a clean microscope slide and were cut $2 \mathrm{~mm}$ from the growing tip. The tips were kept and the rest was discarded. Aceto-carmine stain was added to the slide to cover the root tips for 2-3 minutes. A cover glass was placed on the root tip and the root tip spread evenly to form a monolayer by gently tapping

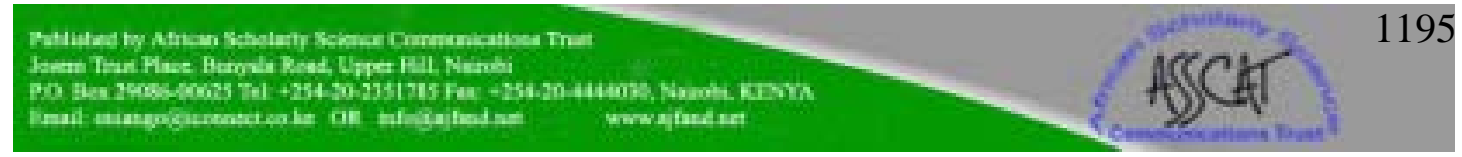


the cover glass with a pencil eraser to facilitate the scoring process for normal and aberrant cells in the different stages of the cell cycle.

\section{Scoring of slides}

The slides were viewed under the light microscope (Olympus CX 21) using the 100X objective with oil immersion. A total of 3000 cells were scored on each slide. The cells were recorded as normal or aberrant in the different stages of the cell cycle namely: interphase, prophase, metaphase, anaphase or telophase. All cells with aberrations were counted and the most representative ones for each abnormality were photographed using a Zeiss PrimoStar microscope mounted with Canon camera model, Power Shot A640.

\section{Data analysis}

\section{Cytotoxicity was determined by the mitotic index}

The Mitotic index was calculated as the number of cells containing visible chromosomes (i.e. cells in the division stages) divided by the total number of cells scored.

The mitotic indices of the treated cells at each dose of pesticide were compared with that of the negative control group. Any dose of a test substance was adjudged to be cytotoxic if the mitotic index of treated cells at that concentration was half or less, compared to the mitotic index of the concurrent water treated cells.

\section{Genotoxicity Assessment}

Dividing cells with any of the under listed abnormalities were recorded, namely;

a. Multipolar anaphases and telophases

b. C-metaphase cells (No spindle fibres)

c. Cells with stick chromosomes

d. Lagging chromosomes

e. Micronuclei or binuclei

f. Acentric chromosome fragments

The number of aberrant cells /1000 cells in each of the four division stages for pesticides treated cells were compared with the numbers for the water treated (negative control) cells by the Mann-Whitney U test using the SPSS 10.0 for Windows statistical package. The calculated $U$ value for each comparison was obtained. If the calculated $U$ value was less than the critical value from the table at the appropriate degrees of freedom (in our own case, $\mathrm{n}_{1}=4$ and $\mathrm{n}_{2}=4$ ) at the 0.05 probability then a statistically significant difference existed between the medians and the pesticide was adjudged to be genotoxic at the dose of the pesticide.

\section{RESULTS}

\section{Cytotoxicity of the pesticides}

The results of the cytotoxicity determination are presented in Table 1. Cells treated with all three pesticides had reduced mitotic indices compared with cells treated with water which was indicative of inhibition of cell division by these pesticides. For all three pesticides, the cytotoxic effects were observed in cells exposed to the top two

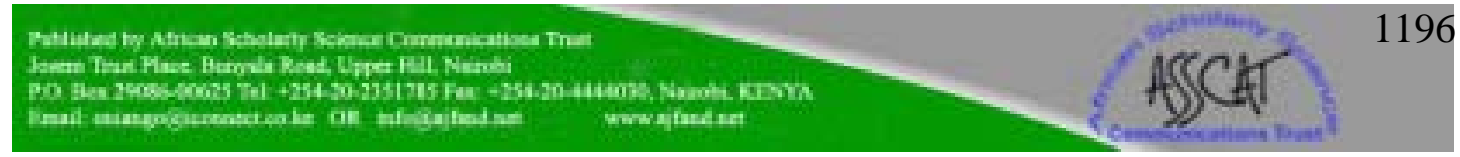


doses but not to the $1 / 4$ LC50 dose. The cytotoxic effects were therefore dose dependent. The positive control chemical, methyl methane sulphonate, at $1 \%$ concentration in water, did not inhibit mitotic cell division of the onion root tip cells.

\section{Genotoxicity of the pesticides}

The genotoxic effects of the pesticides as, determined by comparing the number of aberrant cells in division stages for each dose of each pesticide with those of the concurrent negative control in the Mann-Whitney $U$ test are presented in Table 2.

The genotoxic effects that were observed in the present study included, lagging chromosomes and chromosomes bridges at anaphase and multipolar anaphases and telophases.

A representative picture of a normal metaphase cell and anaphase cell is presented in Figure 1. Representative pictures of the different types of aberrant division stages are presented in Figures $2-5$.

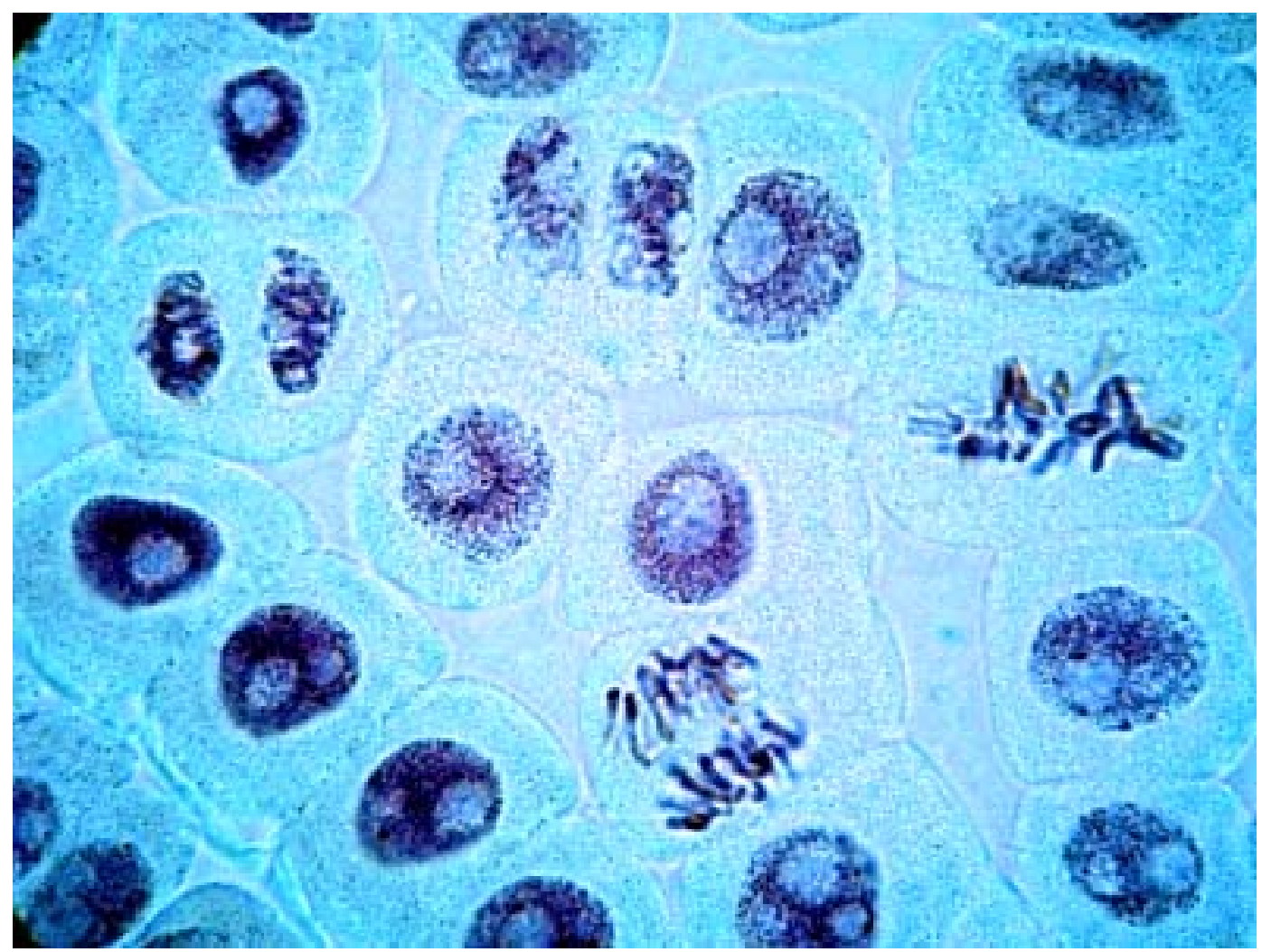

Figure 1: Allium cepa root tip cells not treated with pesticide showing a normal metaphase cell and a normal telophase cell 


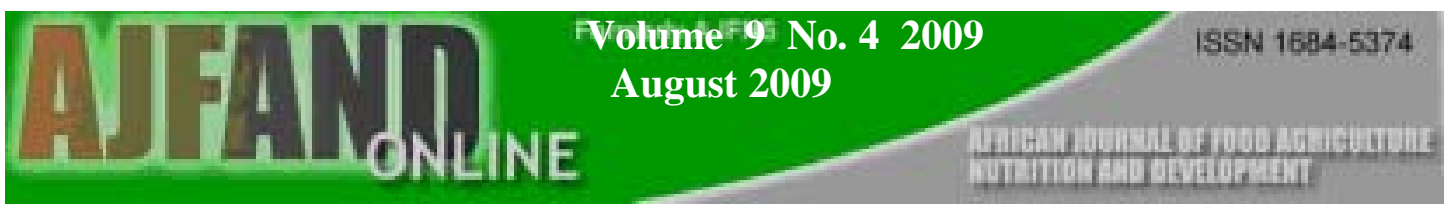

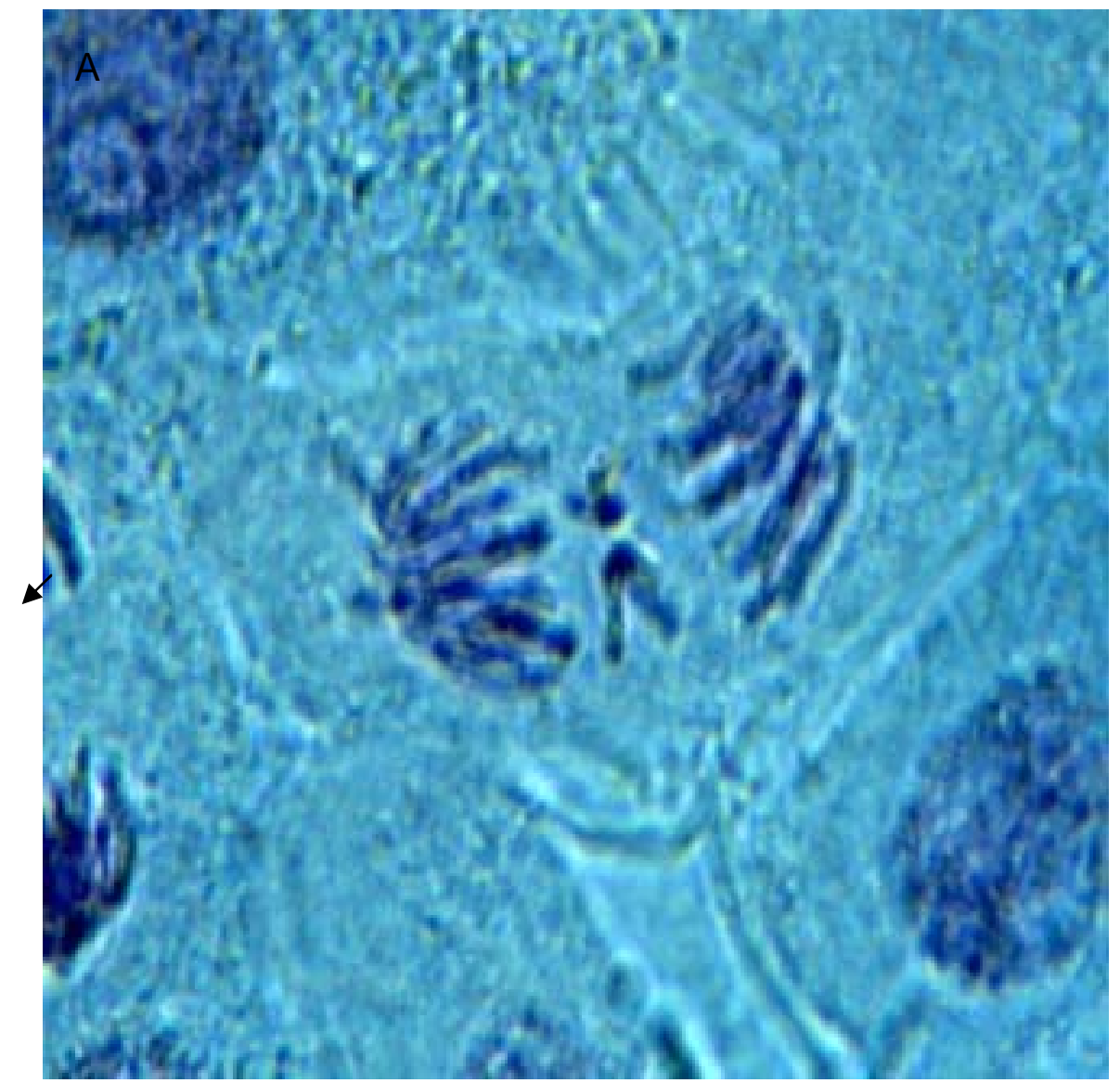

Figure 2: Allium cepa root tip cells treated with pesticide showing a cell at anaphase with lagging chromosomes 

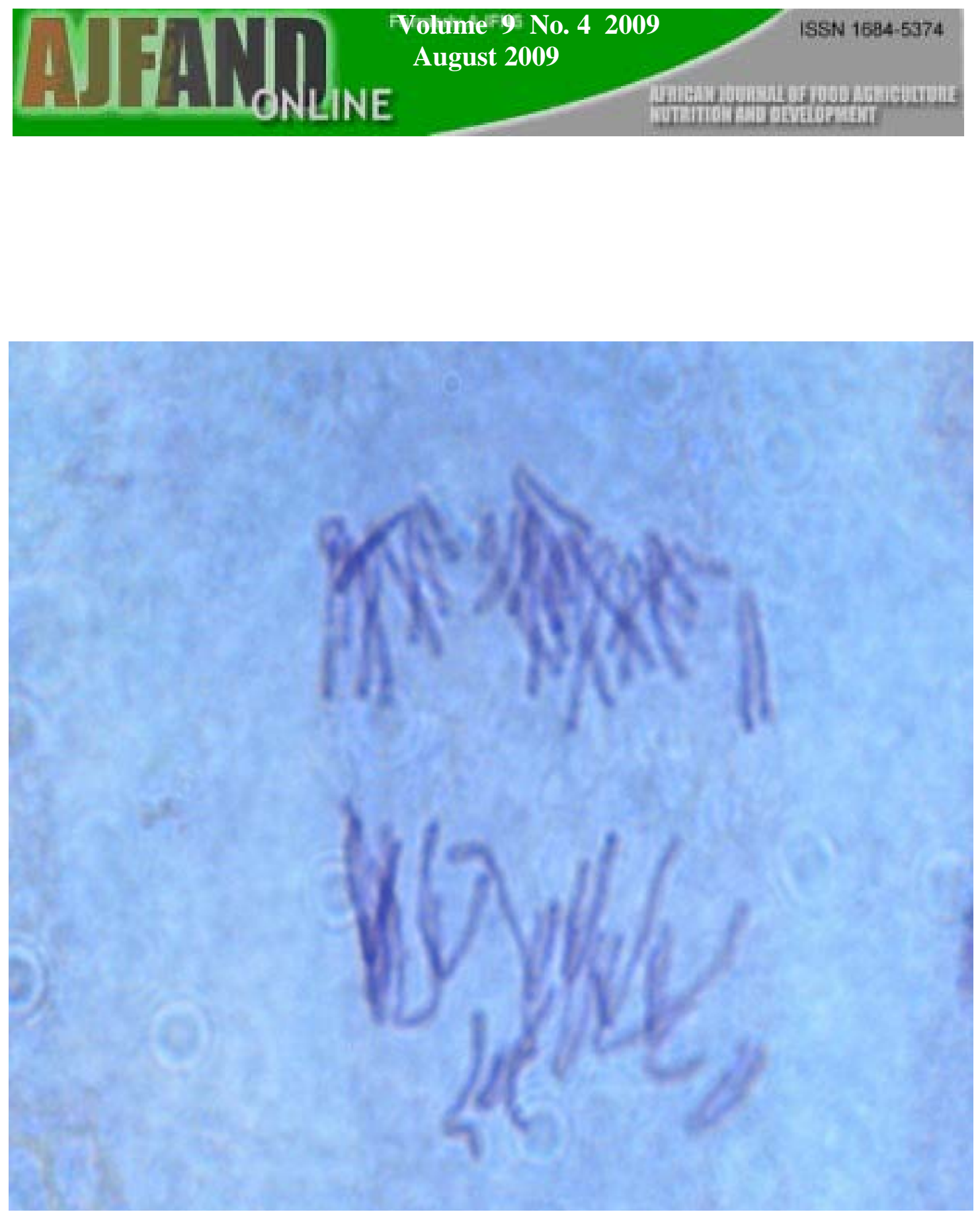

Figure 3: Allium cepa root tip cells treated with pesticide showing a multipolar anaphase cell 

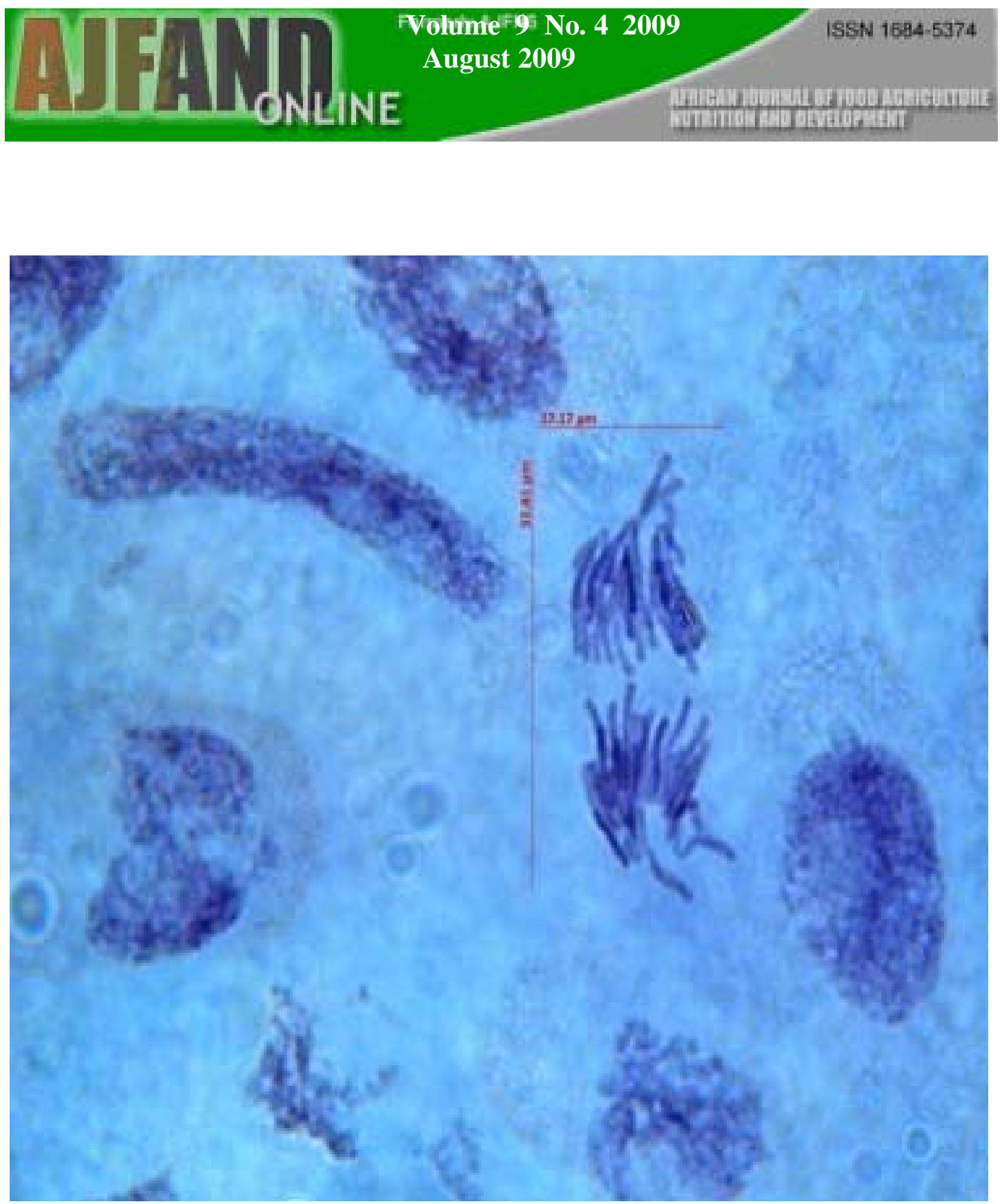

Figure 4: Allium cepa root tip cells treated with pesticide showing a cell at anaphase with chromosome bridge 


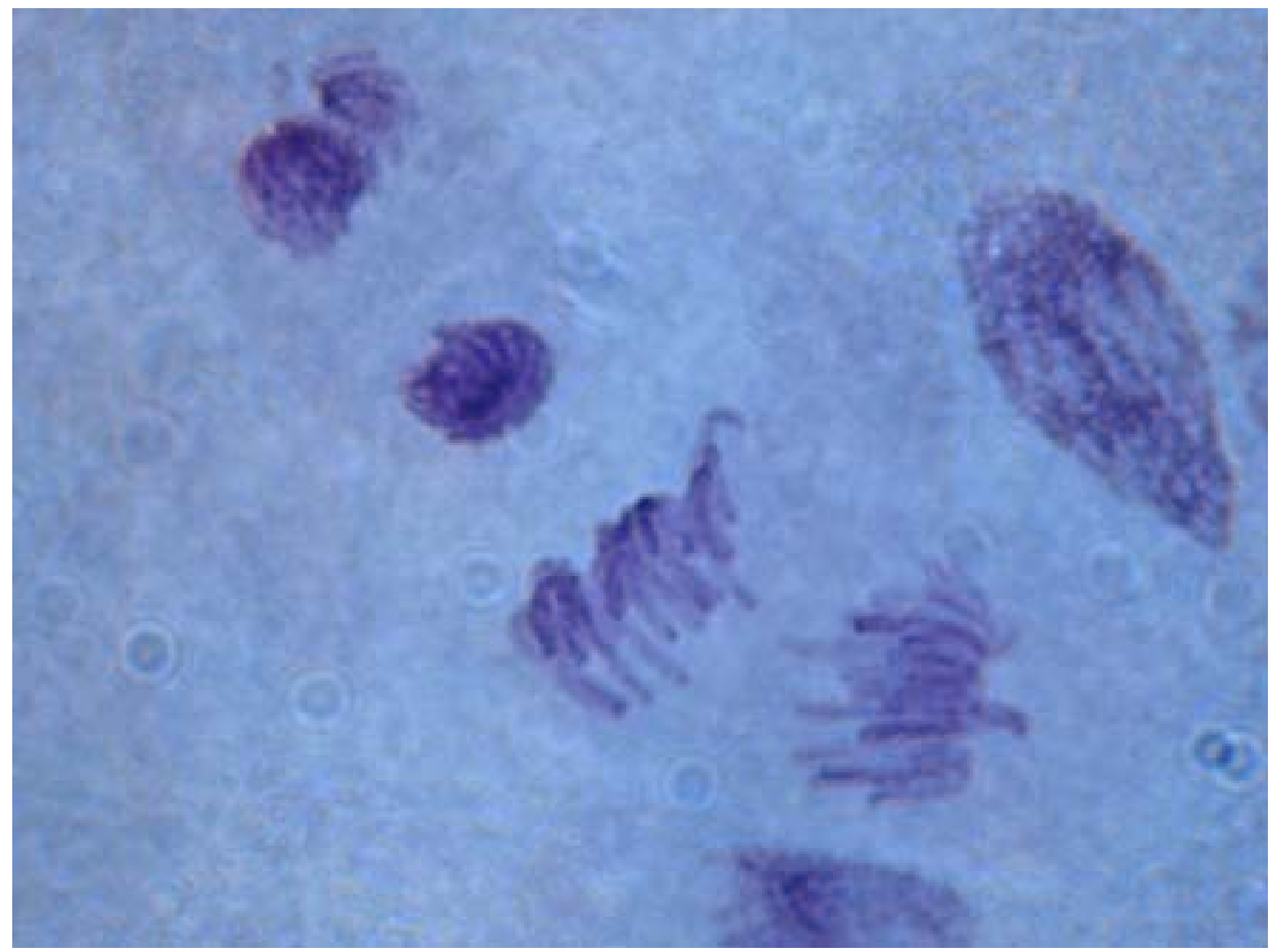

\section{Figure 5: Allium cepa root tip cells treated with pesticide showing a multipolar telophase}

Dithane (at one dose) and malathion (at all three doses) induced significant frequencies of aberrant division stages compared with the water (negative control) treated group, $(\mathrm{P}<0.05)$. They were thus genotoxic. Garden ripcord was not genotoxic at any of the doses of the pesticide tested. The positive control chemical, methyl methane sulphonate, was genotoxic.

Another method of estimating the genotoxic effect of the pesticides involve the calculation of the ratio of aberrant $(\mathrm{ABN})$ to total dividing onion cells $(\mathrm{ABN} /(\mathrm{N}+\mathrm{ABN}))[23]$. When that was applied to the data obtained in this study, it was found that, for the positive control chemical and at all concentrations of dithane and malathion, the aberrant onion cell rate was higher than that recorded for the negative control (Table 2). Garden ripcord was not genotoxic in this analytical procedure too. This method of assessment of genotoxic effect was however not considered in the discussion in the present study. It has been included to highlight the need for standardization. 
The types of aberrations observed in cells treated with the different pesticides are presented in Table 3.

\section{DISCUSSION}

The use of plants for the evaluation of environmental pollutants such as pesticides is becoming common practice because plants are direct recipients of agrotoxics, so they are important material for genetic test and for environmental monitoring of places affected by such pollutants [7]. The higher plants Allium cepa (onion), Tradescantia paludosa and Vicia faba have relatively large monocentric chromosomes in reduced numbers and are accepted as suitable test organisms for the study of environmental mutagenesis $[24,25]$.

The genotoxic effects that were observed in cells treated with the pesticides in the present study included lagging chromosomes and chromosome bridges at anaphase and multipolar anaphase and telophase.

A $1 \%$ solution of the positive control chemical, methyl-methanesulfonate (MMS) was observed to be genotoxic but not cytotoxic to the onion root tip cells in the present study. This agreed with results of Rank and Nielsen [24].

The fungicide dithane, also known as mancozed, was cytotoxic at $0.782 \%$ and 0.391 $\%$ solutions but genotoxic at $0.391 \%$ only to the onion root tip cells in the present study. The toxicity may have masked its potential genotoxicity at the higher dose. It induced multipolar anaphases and telophases and chromosome lagging.

These observations are in agreement with findings in studies with Salmonella typhimurium tester strains TA97a, TA98, TA100, and TA102, in which mancozeb exhibited toxic effect and dose-dependent increases in the number of revertants with and without metabolic activation when it was dissolved in DMSO or acetone [10]. However, mancozed was found to be mutagenic in one set of tests, while in another it did not cause mutations [8]. Mancozeb induced a dose-dependent increase in spindle morphology alterations in preovulatory oocytes of 23-25 day old Swiss CD1 mouse at $1 \mu \mathrm{g} / \mathrm{ml}$ in culture medium [11]. Mancozeb is not taken up from the soil by plants [26]. The observations that dithane caused both cytotoxicity and genotoxicity suggests that the onion root tip cells took up the dithane in the present study.

Malathion exhibited cytotoxicity to the onion root tip cells at the two lower doses and was genotoxic at all three doses tested in the present study. It induced anaphase chromosome lagging.

Malathion produced detectable mutations in three different types of cultured human cells, including white blood cells and lymph cells. However, malathion and its metabolite, malaoxon, gave negative results for genotoxicity tests on S. typhimurium TA97, TA98, and TA100 at doses of 10-1000 $\mu \mathrm{g} /$ plate [27]. The observation of toxicity and genotoxicity of malathion to onion root tip cells in the present study is therefore informative.

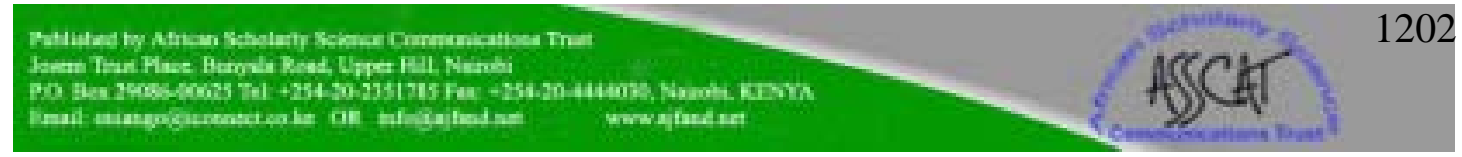


Garden ripcord was toxic at $4.06 \%$ and $2.03 \%$ concentrations only but not mutagenic at any dose tested. In a study that involved the testing of cypermethrin (active ingredient of garden ripcord) for mutagenicity, negative results were observed in Salmonella typhimurium TA 100 or TA 98, in the presence or absence of a rat liver activation system at concentrations of up to $1 \mathrm{mg} /$ plate [21]. According to Thais et al., cypermethrin has been tested in a wide variety of in vitro and in vivo genotoxicity studies and all of the results were negative [6]. Garden ripcord was toxic in the present study with onion root tip assay but cypermethrin was not toxic in the bacteria mutation assay of Pluymen et al. [21]. It has to be noted that Garden ripcord contains $20 \mathrm{~g} / \mathrm{l}$ of cypermethrin. The toxicity observed in the present study could therefore, have been caused by other ingredients in garden ripcord. Differences in activities between pure products and formulations in which the pure product is only one component have been shown for glyphosate, which alone rarely caused genetic damage in laboratory tests (28) and roundup, a glyphosate product, which demonstrated mutagenicity (29).

\section{CONCLUSION}

The present study has, therefore, demonstrated the usefulness of the Allium cepa chromosome aberration assay in assessing the genotoxicity of environmental chemicals.

The observations of the cytoxic and genotoxic effects of these pesticides to onion root tip cells provide additional information about their range of activities in different test systems. 
Table 1: Toxicity of Pesticides to onion root tip cells

\begin{tabular}{|c|c|c|c|c|c|c|c|c|c|}
\hline \multirow{3}{*}{ 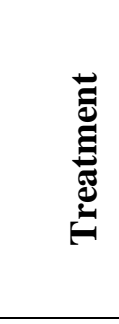 } & \multirow{3}{*}{ 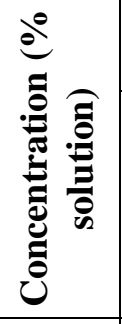 } & \multicolumn{6}{|c|}{ Number of cells in the different stages/1000 cells scored } & \multirow[b]{3}{*}{ MI } & \multirow{3}{*}{ 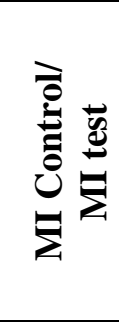 } \\
\hline & & \multirow[b]{2}{*}{ INTERP } & \multicolumn{5}{|c|}{ DIVISION STAGES } & & \\
\hline & & & PROP & METAP & ANAP & TELOP & TOTAL & & \\
\hline Water & 100 & 814.77 & 66.51 & 64.52 & 34.25 & 19.95 & 185.23 & 0.185 & 1.00 \\
\hline MMS & 1.000 & 764.84 & 111.12 & 49.42 & 42.45 & 32.17 & 235.16 & 0.235 & 0.79 \\
\hline DIT & 0.196 & 906.23 & 52.68 & 11.60 & 12.93 & 16.57 & 93.78 & 0.094 & 1.98 \\
\hline & 0.391 & 943.76 & 24.62 & 7.65 & 11.32 & 12.64 & 56.23 & 0.056 & $3.29 *$ \\
\hline & 0.782 & 983.54 & 11.86 & 2.63 & 0.66 & 1.32 & 16.47 & 0.016 & $11.25 *$ \\
\hline MAL & 0.034 & 848.20 & 87.51 & 40.44 & 17.90 & 5.97 & 151.82 & 0.152 & 1.22 \\
\hline & 0.069 & 947.21 & 17.60 & 21.83 & 6.19 & 7.17 & 52.79 & 0.053 & $3.51 *$ \\
\hline & 0.137 & 944.46 & 17.63 & 18.95 & 11.97 & 6.99 & 55.54 & 0.056 & $3.34 *$ \\
\hline GAR & 1.015 & 906.68 & 67.09 & 13.62 & 8.97 & 3.65 & 93.33 & 0.093 & 1.99 \\
\hline & 2.030 & 972.30 & 15.17 & 3.96 & 4.62 & 3.96 & 27.71 & 0.028 & $6.69 *$ \\
\hline & 4.060 & 984.06 & 7.97 & 3.32 & 1.99 & 2.66 & 15.94 & 0.016 & $11.62 *$ \\
\hline
\end{tabular}


Table 2: Mutagenic potencies of the Pesticides to onion root tip cells

\begin{tabular}{|c|c|c|c|c|c|c|c|c|c|c|c|c|c|}
\hline \multirow{3}{*}{ 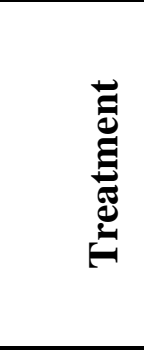 } & \multirow{3}{*}{ 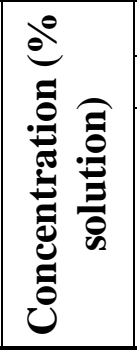 } & \multicolumn{10}{|c|}{ Number of cells in the different division stages/1000 cells scored } & \multicolumn{2}{|c|}{ Mutagenicity } \\
\hline & & \multicolumn{2}{|c|}{ PROP } & \multicolumn{2}{|c|}{ METAP } & \multicolumn{2}{|c|}{ ANAP } & \multicolumn{2}{|c|}{ TELOP } & \multicolumn{2}{|c|}{ TOTAL } & \multirow{2}{*}{ 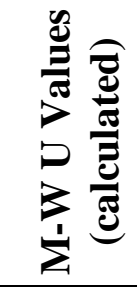 } & \multirow{2}{*}{ 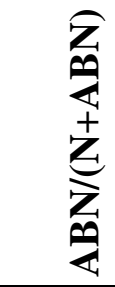 } \\
\hline & & $\mathbf{N}$ & $\mathbf{A B N}$ & $\mathbf{N}$ & $\mathbf{A B N}$ & $\mathbf{N}$ & $\mathbf{A B N}$ & $\mathbf{N}$ & $\mathbf{A B N}$ & $\mathbf{N}$ & $\mathbf{A B N}$ & & \\
\hline Water & 100 & 66.51 & 0.00 & 64.52 & 0.00 & 34.25 & 0.00 & 19.95 & 0.00 & 1000.00 & 0.00 & & 0.00 \\
\hline MMS & 1.000 & 90.22 & 20.90 & 33.17 & 16.25 & 30.51 & 11.94 & 26.20 & 5.97 & 914.43 & 85.57 & $0 \dagger$ & $0.23 \div$ \\
\hline \multirow[t]{3}{*}{ DIT } & 0.196 & 52.68 & 0.00 & 11.60 & 0.00 & 11.60 & 1.33 & 16.24 & 0.33 & 997.35 & 2.65 & 4 & $0.02 \ddagger$ \\
\hline & \begin{tabular}{|l|}
0.391 \\
\end{tabular} & 22.96 & 1.66 & 7.32 & 0.33 & 10.65 & 0.67 & 12.31 & 0.33 & 997.00 & 3.00 & $0 \dagger$ & $0.05 \ddagger$ \\
\hline & \begin{tabular}{|l|}
0.782 \\
\end{tabular} & 9.88 & 1.98 & 2.30 & 0.33 & 0.66 & 0.00 & 0.66 & 0.66 & 977.61 & 22.39 & 2 & $0.18 \div$ \\
\hline \multirow[t]{3}{*}{ MAL } & 0.034 & 81.21 & 6.30 & 36.13 & 4.31 & 14.92 & 2.98 & 4.31 & 1.66 & 967.19 & 32.81 & $0 \dagger$ & $0.10 \neq$ \\
\hline & 0.069 & 15.97 & 1.63 & 17.27 & 4.56 & 1.63 & 4.56 & 6.52 & 0.65 & 979.47 & 20.53 & $0 \dagger$ & $0.22 \ddagger$ \\
\hline & 0.137 & 12.64 & 4.99 & 11.97 & 6.98 & 6.32 & 5.65 & 4.99 & 2.00 & 956.77 & 43.23 & $0 \dagger$ & $0.35 \ddagger$ \\
\hline \multirow[t]{3}{*}{ GAR } & 1.015 & 67.09 & 0.00 & 13.62 & 0.00 & 8.97 & 0.00 & 3.65 & 0.00 & 1000.00 & 0.00 & 8 & 0.00 \\
\hline & 2.030 & 15.17 & 0.00 & 3.96 & 0.00 & 4.62 & 0.00 & 3.96 & 0.00 & 1000.00 & 0.00 & 8 & 0.00 \\
\hline & 4.060 & 7.97 & 0.00 & 3.32 & 0.00 & 1.99 & 0.00 & 2.66 & 0.00 & 1000.00 & 0.00 & 8 & 0.00 \\
\hline \multicolumn{14}{|c|}{$\begin{array}{l}\text { Key: PROP = Prophase; METAP = Metaphase; ANAP = Anaphase; TELOP = Telophase; } \mathrm{M}-\mathrm{W}=\text { Mann- } \\
\text { Whitney; N=Normal; ABN= Abnormal; DIT = Dithane; MAL = Malathion; GAR = Garden Ripcord; } \dagger= \\
\text { Genotoxic }(\mathrm{U} \leq 0 ; \mathrm{P}<0.05 \text {, Mann-Whitney } \mathrm{U}-\text { test }) ;=\text { Genotoxic: }(\mathrm{ABN} /(\mathrm{N}+\mathrm{ABN})) \text { at a test concentration } \\
>(\mathrm{ABN} /(\mathrm{N}+\mathrm{ABN})) \text { of concurrent of negative control. }\end{array}$} \\
\hline
\end{tabular}


Table 3: Types of mutation induced by the different pesticides

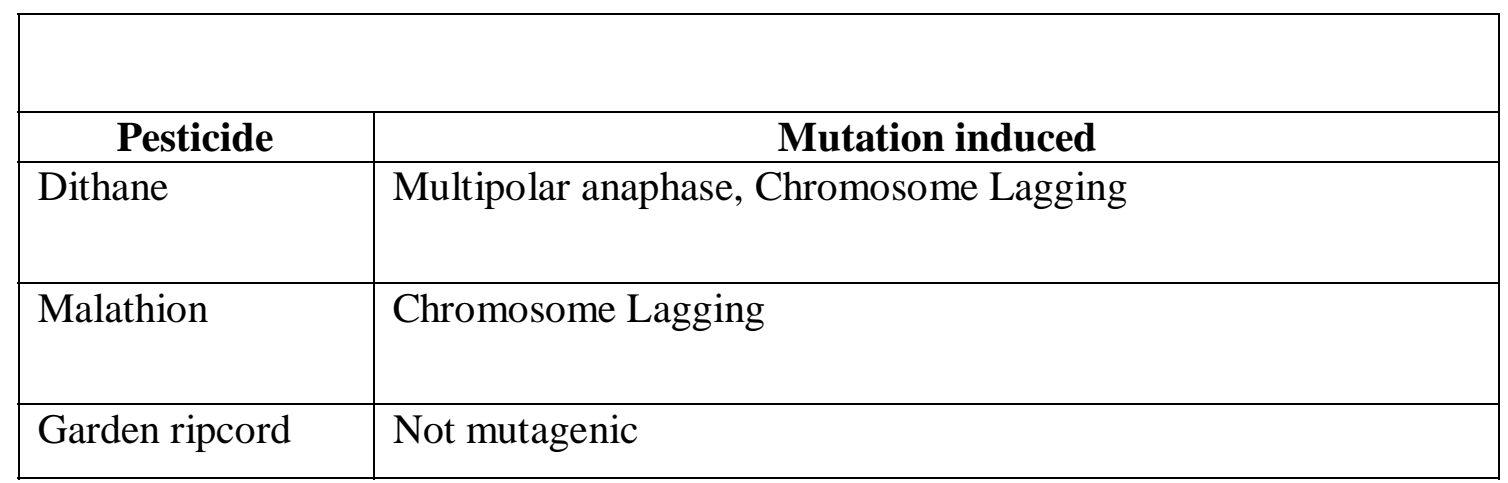




\section{REFERENCES}

1. Taylor D, Green $\mathbf{N}$ and G Stout Biological Science. $3^{\text {rd }}$ edition Cambridge University Press: Australia 1997.

2. Pastor S, Creus A, Parrón T, Cebulska-Wasilewska A, Siffel C, Piperakis S and $\mathbf{R}$ Marcos Biomonitoring of four European populations occupationally exposed to pesticides: use of micronuclei as biomarkers. Mutagenesis 2003; 18 (3): 249-258.

3. Commission to the European Parliament and the Council Evaluation of the Active Substances of Plant Protection Products, EEC Commission, Brussels, Belgium. 2001 SANCO 822/2001 rev. 3.

4. International Agency for Research on Cancer (IARC) Monographs on the Evaluation of Carcinogenic Risks to Humans, Occupational Exposures in Insecticide Application and Some Pesticides. IARC, Lyon, 1991; 53: 33-586.

5. Mukhopadhyay I, Chowdhuri DK, Bajpayee M and A Dhawan Evaluation of in vivo genotoxicity of cypermethrin in Drosophila melanogaster using the alkaline Comet assay. Mutagenesis 2004; 19(2): 85-90.

6. Thaís C, Dânia Elisa C and A Maria Pesticide Biochemistry and Physiology. Mechanism of micronuclei formation. In: Polyploidizated cells of Allium cepa exposed to trifluralin herbicide. 2007; 88 (3): 252-259.

7. Cabrera Ma TH GL, Cebulska-Wasilewska A, Chen R, Loarca F, Vandererg AL and MF Salamone Tradescantia-Stamen-Hair-Mutation Bioassay- A Collaborative Study on Plant Genotoxicity Bioassays for the International Program on Chemical Safety, WHO, The United Nations. 1994; 310: 211-220.

8. Environmental Protection Agency (EPA) Pesticide fact sheet: Mancozeb. Registration Standard. Office of Pesticides and Toxic Substances. Office of Pesticide Programs. Washington, DC. 1987 April.

9. Environmental Protection Agency (EPA) Ethylene bisdithiocarbamates (EBDCs); Notice of intent to cancel and conclusion of Special Review. Federal Register US GAO, Washington, DC. 1992; 57(41): 7434-7530.

10. Shukla Y, Taneja P, Arora A and N Sinha Mutagenic Potential of Mancozeb in Salmonella typhimurium. Journal of Environmental Pathology, Toxicology and Oncology 2004; 23(4): 60-65.

11. Stricker SA, Roberto S and T Smythe Calcium and Endoplasmic Reticulum Dynamics during Oocyte Maturation and Fertilization in the Marine Worm Cerebratulus lacteus. Developmental Biology 1998; 203(2): 305-322.

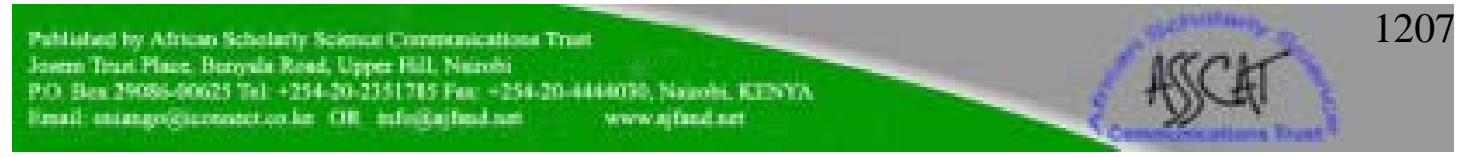


12. Environmental Protection Agency (EPA) Chemicals Evaluated for Carcinogenic Potential, Science Information Management Branch, Health Effects Division, Office of Pesticide Program. 2002; May.

13. Extension Toxicology Network (EXTOXNET) Pesticide Information Profile Malathion. 1993; September.

14. Kegley S, Hill B and S Orme Chlorpyrifos - Identification, toxicity, use, water pollution potential, ecological toxicity and regulatory information. Pesticide Action Network. North America (San Francisco, CA. 2007).http: www.pesticideinfo.org. Accessed on $20^{\text {th }}$ April 2008.

15. National Research Council Drinking Water and Health. Advisory Center on Toxicology, Assembly of Life Sciences. Safe Drinking Water Committee, National Academy of Sciences, Washington, DC. 1977.

16. Food and Agricultural Organization (FAO) Pesticide residues in food-1979. Report of the Joint Meeting of the FAO Panel of Experts on Pesticide Residues in Food and the Environment and the WHO Expert Group on Pesticide Residues. Rome, Food and Agriculture Organization of the United Nations (FAO Plant Production and Protection Paper, No. 20) 1980.

17. Food and Agricultural Organization (FAO) Pesticide residues in food-1981. Report of the Joint Meeting of the FAO Panel of Experts on Pesticide Residues in Food and the Environment and the WHO Expert Group on Pesticide Residues. Rome, Food and Agriculture Organization of the United Nations (FAO Plant Production and Protection Paper, No. 37) 1982.

18. U.S. Agency for Toxic Substances and Disease Registry (ATSDR) Toxicological profile for Pyrethrins and Pyrethroids. 2003 September.

19. Casida JE, Gammon DW and AH Glickman Mechanisms of selective action of pyrethroid insecticides. Ann Rev Pharmacol Toxicol. 1983; 23: 413-438.

20. Aprea C, Stridori A and G Sciarra Analytical method for the determination of urinary 3-phenoxybenzoic acid in subjects occupationally exposed to pyrethroid insecticides. J Chromatogr B Biomed Appl. 1997; 695: 227-236.

21. Pluymen M, Drevon C, Montesano R, Malaveille C, Hautefeuille A and $\mathbf{H}$ Bartsch Lack of mutagenicity of synthetic pyrethroids in Salmonella typhimurium strains and in V79 Chinese hamster cells. Mutat. Res. 1984; 137: 7-15.

22. Bhunya SP and PC Pati Genotoxic effects of a synthetic pyrethroid insecticide, cypermethrin, in mice in vivo. Toxicol Lett. 1988; 41: 223-230. 
23. Matsumoto S, Mantovani M, Rigonato J and M Marin-Morales Evaluation of the Genotoxic Potential of the action of an effluent contaminated with Chromium, by the comet assay in CHO-ki cultures. Caryologia 2006; 58: 40-46.

24. Rank J and M Nielsen Genetoxicity Testing of Wastewater Sludge using the Allium cepa Anaphase-telophase chromosome Aberration Assay. Mutat. Res. 1998; 418: 113-119.

25. Patra M and A Sharma Relative efficacy of Allium cepa and Allium sativum in anaphase-telophase test screening metal genotoxicity. Biologia 2002; 57: 409414.

26. Harding WC Pesticide profiles, part one: insecticides and miticides. University of Maryland. Cooperative Extension Service. Bulletin 1979; 267.

27. Imamura $\mathbf{T}$ and $\mathbf{R}$ Talcott Mutagenic and alkylating activities of organophosphate impurities of commercial malathion. Mutat. Res. 1985; 155: 16.

28. Environmental Protection Agency (EPA) Office of Pesticide Programs. Special Review and Reregistration Division. Re-registration eligibility decision (RED): Glyphosate. Washington, D.C. 1993 (September).

29. Rank J, Jensen AG, Skov B, Pedersen LH and K Jensen Genotoxicity testing of the herbicide Roundup and its active ingredient glyphosate isopropylamine using the mouse bone marrow micronucleus test, Salmonella mutagenicity test, and Allium anaphase-telophase test. Mutat. Res. 1993; 300:2936. 